\title{
„AMBASADY” REGIONÓW - PRZEDSTAWICIELSTWA POLSKICH WOJEWÓDZTW W BRUKSELI
}

\author{
Beata Surmacz \\ Zakład Stosunków Międzynarodowych, Uniwersytet Marii Curie-Skłodowskiej w Lublinie \\ Plac Litewski 3, 20-080 Lublin; beata.surmacz@poczta.umcs.lublin.pl
}

\begin{abstract}
Streszczenie. Celem artykułu jest przedstawienie form organizacyjnych, funkcji oraz aktywności biur regionalnych polskich województw w Brukseli, a także próba oceny ich funkcjonowania. Pierwsze biura regionalne w Brukseli zaczęły powstawać w połowie lat 80 . XX w. Obecnie funkcjonuje ich ponad 300. Wśród nich są reprezentowane wszystkie województwa. Polskie biura regionalne posiadają status bądź samodzielnej jednostki budżetowej, bądź delegatury urzędu marszałkowskiego. Nie posiadają statusu dyplomatycznego, ale są swoistymi „ambasadami” województw. Główne funkcje biur regionalnych to: funkcja informacyjna, lobbingowa, promocyjna, networking oraz funkcja wspierająca władze regionalne $\mathrm{w}$ ich kontaktach $\mathrm{z}$ instytucjami UE. Funkcjonowanie polskich biur regionalnych jest oceniane bardzo różnie. Często pojawiają się pytania o celowość otwierania biur oraz wątpliwości dotyczące współmierności kosztów funkcjonowania i efektów ich pracy.
\end{abstract}

Słowa kluczowe: regiony, biura regionalne, paradyplomacja, Unia Europejska

\section{WSTĘP}

Ewolucja struktury podmiotowej stosunków międzynarodowych sprawia, że państwa przestały być jedynymi podmiotami uczestniczącymi w stosunkach międzynarodowych, co prawda zachowują nadal swoją szczególną pozycję w środowisku międzynarodowym, ale zmieniają się warunki ich funkcjonowania i wykonywania suwerenności. Nastąpił wzrost liczby i aktywności różnorodnych podmiotów innych niż państwo, w tym aktorów subpaństwowych w postaci regionów. Jest to tendencja szczególnie widoczna w UE, gdzie jest bardzo rozwinięta sieć kontaktów regionalnych. Aktywne są niemieckie landy, szwajcarskie kantony czy nawet polskie województwa. Poszczególne regiony tworzą swoiste „ambasady” w Brukseli, które mają za zadanie reprezentowanie interesów swoich regionów.

Od połowy lat osiemdziesiątych Bruksela, obok Waszyngtonu, stała się centrum międzynarodowego lobbingu. Szacuje się, że funkcjonuje tam ponad 15000 lobbystów i 2500 organizacji lobbystycznych, z tego ponad 300 przedstawicielstw regionów i miast. Swoje interesy w Brukseli, oprócz państw, reprezentują:

- organizacje zawodowe, 
- organizacje biznesowe,

- stowarzyszenia ekologiczne,

- organizacje konsumenckie,

- organizacje reprezentujące interesy społeczne,

- władze regionalne i lokalne ${ }^{1}$.

Charakter obecności regionów w Brukseli jest bardzo urozmaicony pod względem misji, zasobów, personelu czy pełnionych funkcji. Możliwe są różne formy reprezentacji interesów regionalnych w Brukseli ${ }^{2}$ :

- Wynajęcie zawodowego lobbysty. Wiąże się to z wysokimi kosztami ekspertyz, także z tym, że ekspertyzy mogą nie odpowiadać potrzebom regionu, ze względu na nieznajomość przez eksperta specyfiki regionu.

- Bezpośrednie przedstawicielstwo: otwarcie biura i utrzymywanie stałego przedstawiciela. Zalety tego rozwiązania to: możliwość tworzenia własnej tożsamości wobec instytucji unijnych; skoncentrowanie działalności na priorytetach i zadaniach wypracowanych przez władze regionalne; uniknięcie nieporozumień o „nierównomierne” reprezentowanie interesów poszczególnych partnerów ${ }^{3}$. Niewątpliwie jednak jest to jedna z najbardziej kosztownych form reprezentacji.

- Pośrednie przedstawicielstwo poprzez zaprzyjaźnione regiony lub wyspecjalizowane instytucje. To rozwiązanie daje możliwość korzystania z doświadczeń biura regionu partnerskiego oraz ewentualną pomoc w nawiązywaniu kontaktów.

- Hot desk: e-mail, telefon, faks, krótkie wizyty w Brukseli. Ta forma reprezentacji gwarantuje niskie koszty, możliwość wysłania pracownika do Brukseli $\mathrm{w}$ odpowiednim momencie. Z drugiej strony jednak, krótki okres pobytu skutkuje małą możliwością nawiązywania własnych kontaktów.

- Sieci europejskie.

Do najskuteczniejszych form zalicza się bezpośrednie, stałe przedstawicielstwa regionów w Brukseli. Celem artykułu jest przedstawienie form organizacyjnych, funkcji oraz aktywności biur regionalnych polskich województw w Brukseli, a także próba oceny ich funkcjonowania.

\section{POCZĄTKI BIUR W BRUKSELI}

Powstanie pierwszych biur regionalnych w Brukseli datuje się na połowę lat 80., kiedy rozpoczęly funkcjonowanie dwa pierwsze tego typu przedstawicielstwa: City of Birmingham (1984) oraz niemiecki region Saary (1985). Pionierami na tym polu były więc brytyjskie i niemiecki władze lokalne i regional-

\footnotetext{
${ }^{1}$ Zob. J. Greenwood, Interest Representation in the European Union, Basingstoke 2007.

${ }^{2}$ U. Kurczewska, M. Molęda-Zdziech, Lobbing w Unii Europejskiej, Warszawa 2002, s. 202-203.

${ }^{3}$ S. Mrozowska, Polski lobbing regionalny w Unii Europejskiej, w: J. Marszałek-Kawa (red.), Polska w Unii Europejskiej. Bilans otwarcia, Toruń 2005.
} 
ne. O ile przedstawicielstwa brytyjskie były tworzone przede wszystkim z myślą o pozyskiwaniu funduszy strukturalnych, reprezentacje landów niemieckich powstawały bardziej z powodów politycznych ${ }^{4}$. Początkowo działalność biur regionalnych była dosyć negatywnie oceniana przez władze centralne państw członkowskich, które odbierały to jako próbę samodzielnego prowadzenia polityki zagranicznej. Zakaz ustanawiania przedstawicielstw regionalnych w Brukseli obejmował np. Włochy czy Hiszpanię do połowy lat 90.

Od momentu powstania pierwszych biur ich liczba systematycznie i lawinowo rosła: 1984 r. - 2 biura, 1988 - 17, 2000 - 199, 2012 - ponad 300. Spośród państw członkowskich UE biur regionalnych w Brukseli nie posiadają jedynie Luksemburg, Malta i Portugalia ${ }^{5}$. Proces tworzenia przedstawicielstw regionalnych w Brukseli przybrał na sile w latach 90. po wejściu w życie Traktatu z Maastricht, na mocy którego wzrosła rola regionów w kreowaniu polityki społeczno-ekonomicznej Unii Europejskiej. Możliwość kształtowania polityki strukturalnej stała się dla regionów impulsem do zakładania biur regionalnych. W Traktacie znalazły się przepisy o utworzeniu nowego organu doradczego UE, mianowicie Komitetu Regionów. Po raz pierwszy władzom regionalnym i lokalnym przyznano prawo opiniowania różnych polityk unijnych ${ }^{6}$. Druga fala wzrostu powiązana była z rozszerzeniem Unii Europejskiej w 2004 r. Przy czym regiony z nowych państw członkowskich zaczęły bardziej masowo tworzyć swoje przedstawicielstwa już w latach 2002-2003.

Początkowo głównym powodem instytucjonalizowania obecności części regionów europejskich w Brukseli były powody finansowe, związane z maksymalizowaniem wpływu na dystrybucję środków finansowych. Obecnie powody finansowe wciąż pozostają istotne, aczkolwiek „walka” o pieniądze dla regionu raczej przeniosła się na areny krajowe, gdzie jest prowadzony najbardziej intensywny lobbing.

Drugim istotnym pierwotnym powodem, wobec wzrastającego wpływu legislacji UE na szczebel lokalny i regionalny, była możliwość wpływania na procesy decyzyjne i legislacyjne. Na przestrzeni lat instytucjonalna i proceduralna struktura Unii Europejskiej ewoluowała, włączając reprezentację regionów w procesy formułowania i implementacji polityk wspólnotowych. Oprócz kontaktów formalnych - przez różne instytucje UE - istotne są również kontakty osobiste, nieformalne? ${ }^{7}$.

\footnotetext{
${ }^{4}$ M. Huysseune, M.T. Jans, Brussels as the capital of a Europe of the regions? Regional offices as European policy actors, „Brussels Studies” 2008, $\mathrm{nr}$ 16, http://www.brusselsstudies.be/medias/publications/EN_57_BruS16EN.pdf (dostęp: 21.11.2011, 30.08.2012).

5 Zob. List of Regional Offices based in Brussels (stan na 31.12.2012), cor.europa.eu/en/regions/.../regional-offices.xls.

${ }^{6}$ M.L. Löper, Biura przedstawicielskie regionów europejskich w Brukseli, „Studia Europejskie", 1/2000, s. 53

${ }^{7}$ C. Ross, Wtadze lokalne a lobbing w Unii Europejskiej, Warszawa 2000, s. 30-33.
} 
Innymi powodami były możliwości skutecznego lobbingu interesów regionalnych, ale również umacnianie regionalnej tożsamości wewnątrz własnego państwa (legitymacja polityczna). Niektóre regiony (np. Kraj Basków, Katalonia czy Szkocja) zaczęły postrzegać Unię Europejską, a zwłaszcza Komisję, jako źródło cennej legitymizacji. Dialog bezpośredni i włączanie regionów w proces formułowania i implementacji polityk wspólnotowych UE nadaje im znaczenie polityczne. Należy również zauważyć działanie efektu spill-over: pomyślne funkcjonowanie biur zakładanych przez jedne regiony stymulowało inne do tworzenia podobnych placówek.

Pierwszym polskim biurem regionalnym w Brukseli było Biuro Informacyjne Województwa Lubelskiego i Podlaskiego, założone w połowie roku 1999 na mocy porozumienia marszałków obydwu województw, a także uchwał Sejmików Województwa Lubelskiego i Podlaskiego ${ }^{8}$. Było to również jedno z pierwszych biur utworzonych przez regiony państw kandydujących do Unii Europejskiej. Dużą pomoc władzom regionalnym okazały władze holenderskiej prowincji Gelderland, który umożliwiły odbycie w brukselskim biurze regionalnym prowincji stażu przedstawicielowi województwa lubelskiego ${ }^{9}$. Idea powołania pierwszego wspólnego biura reprezentacyjnego regionów polskich w Brukseli spotkała się z życzliwym zainteresowaniem MSZ i MSWiA, a także przedstawicielstwa RP przy Unii Europejskiej. Jednakże, jak podkreślały władze województwa, wsparcie to miało jedynie charakter duchowy ${ }^{10}$, a procedura uzgadniania z MSZ treści projektów umów o współpracy zagranicznej województwa oraz uzyskania zgody na powołanie biura w Brukseli była długa i zawiła. Ostatecznie w lutym 2000 roku otrzymano zgodę Ministerstwa Spraw Zagranicznych na utworzenie biura regionalnego, a we wrześniu 2000 roku zostało ono oficjalnie zarejestrowane przez władze miejskie w Brukseli.

Na mocy porozumienia marszałków województw ustalono, że oddelegowany do pracy $\mathrm{w}$ Brukseli pracownik przedstawicielstwa będzie zatrudniony w Urzędzie Marszałkowskim w Białymstoku, a koszty funkcjonowania biura będą pokrywane przez województwa $\mathrm{w}$ równych częściach $^{11}$. Biuro nie było autonomiczną jednostką, ale posiadało status departamentu Urzędu Marszałkowskiego $^{12}$. Do głównych zadań przedstawicielstwa należało: wspieranie działań związanych z podnoszeniem poziomu wiedzy mieszkańców województw

${ }^{8}$ Zob. Porozumienie Marszalków Województw Lubelskiego i Podlaskiego z 9 czerwca 1999 roku o utworzeniu Biura Informacyjnego Regionów Lubelskiego i Podlaskiego w Brukseli (w posiadaniu autora).

9 Przedstawicielem tym, a później pierwszym pracownikiem i organizatorem biura lubelskopodlaskiego w Brukseli była Lucyna Kamińska. Zob. Protokót Nr VIII/03 Sejmiku Województwa Lubelskiego z 28 kwietnia 2003 r., http://www.um.bip.lublin.pl/index.php?id=55\&data=2003-04-28 (dostęp: 24.09.2012]).

${ }^{10}$ Ibidem.

${ }^{11}$ Ibidem.

${ }^{12}$ U. Kurczewska, M. Molęda-Zdziech, op. cit., s. 136-137. 
z zakresu problematyki europejskiej; zdobywanie i przekazywanie informacji o zasadach funkcjonowania UE, a także o możliwościach i zasadach korzystania z programów pomocowych; udzielanie wsparcia na forum instytucji europejskich $\mathrm{w}$ zakresie inicjatyw regionalnych i lokalnych oraz utrzymywanie kontaktów z przedstawicielami dyplomatycznymi RP w Brukseli, krajową i regionalną administracją publiczną i instytucjami odpowiedzialnymi za integrację europejską. Wspólne biuro przedstawicielskie działało do 2003 r., kiedy to z uwagi na wysokie koszty jego funkcjonowania i niską efektywność Zarząd Województwa Podlaskiego podjął decyzję o wystąpieniu z porozumienia ${ }^{13}$.

Do maja 2004 r., a więc do momentu wstąpienia Polski do UE, w Brukseli funkcjonowało jedenaście polskich przedstawicielstw regionalnych. Obecnie wszystkie województwa są reprezentowane przez biura regionalne. Jako ostatnie w 2006 r. dołączyło województwo podkarpackie.

\section{FORMA PRZEDSTAWICIELSTWA}

Forma przedstawicielstwa zależna jest przede wszystkim od stopnia podziału administracyjnego, stopnia decentralizacji państwa i środków finansowych. Istnieje kilka typologii biur regionalnych. Najbardziej uniwersalna i znana jest klasyfikacja A. Heichlingera, która wyodrębnia sześć typów biur przedstawicielskich regionów europejskich ${ }^{14}$. Są to:

1. biuro indywidualne, które reprezentuje władze jednego regionu (większość polskich biur regionalnych);

2. konsorcjum władz regionalnych lub/i lokalnych, tworzone przez grupę władz lokalnych, powstaje na bazie podobnych cech geograficznych, interesów politycznych czy gospodarczych;

3. biuro zrzeszenia władz samorządowych, jako ogólna reprezentacja władz szczebla regionalnego i lokalnego z kraju;

4. biuro ,parasol”, tworzone z inicjatywy władz centralnych kraju, oferujące usługi lobbingowe dla wielu podmiotów publicznych i prywatnych;

${ }^{13}$ Władze województwa podlaskiego uzasadniały swoją decyzję następująco: „Według sporządzanych corocznie preliminarzy kosztów, wydatki związane z utrzymaniem Biura w ciągu roku przekraczały 100 tys. zł dla każdej ze stron, ponadto pracownikiem biura była osoba delegowana Z województwa lubelskiego. Z uwagi na tak wysokie koszty, 24 marca 2003 r. Sejmik Województwa Podlaskiego jednogłośnie podjął uchwałę akceptującą oświadczenie Zarządu Województwa Podlaskiego o wystąpieniu z porozumienia o utworzeniu przedstawicielstwa Województw Podlaskiego i Lubelskiego w Brukseli”. Zob. http://www.wrotapodlasia.pl/NR/exeres/0C898C39-A478462A-8EFE-A17D91101FE4.htm (dostęp: 12.10.2012).

${ }^{14}$ A. Heichlinger, A Regional Representation in Brussels: the Right Idea for Influencing EU Policy Making?, Maastricht 1999, s. 9-13. 
5. biuro partnerskie, tworzone z inicjatywy grupy niezależnych podmiotów szczebla regionalnego i lokalnego, które wspólnie rozwiązują problemy o charakterze europejskim;

6. biuro transnarodowe, reprezentujące interesy ugrupowania współpracy transgranicznej (biuro euroregionu).

Większość polskich biur regionalnych są to przedstawicielstwa pierwszego typu. Posiadają status bądź samodzielnej jednostki budżetowej, bądź delegatury urzędu marszałkowskiego. Samodzielną jednostką budżetową są biura województw: warmińsko-mazurskiego, śląskiego, dolnośląskiego oraz zachodniopomorskiego. Są one nadzorowane przez wyznaczone departamenty urzędów marszałkowskich, ale posiadają znaczną samodzielność w podejmowaniu decyzji. 11 biur regionalnych znajduje się w strukturach urzędów marszałkowskich. Ulokowane są w różnych departamentach, przeważnie związanych ze współpracą międzynarodową czy promocją regionu, ale również funkcjonują w strukturach Gabinetu Marszałka czy Kancelarii Zarządu ${ }^{15}$. Są więc niejako „przedłużeniem władz regionalnych" w Brukseli. W biurze zatrudnieni są pracownicy urzędu marszałkowskiego oddelegowani do Brukseli, którzy nie mają praktycznie możliwości podejmowania samodzielnych decyzji i na wszelkie działania muszą uzyskać zgodę przełożonego.

Do przedstawicielstw drugiego typu należało wspólne przedstawicielstwo województw lubelskiego i podlaskiego, które działało do 2003. Obecnie, do pewnego stopnia, tego typu konsorcjum jest Dom Polski Wschodniej (jako konsorcjum regionów), a także przedstawicielstwo województwa łódzkiego (samorząd regionalny + miasto Łódź). Dom Polski Wschodniej to wspólne przedstawicielstwo regionów Polski Wschodniej powstałe na mocy porozumienia zawartego 2 grudnia 2009 r. w Brukseli pomiędzy województwami: lubelskim, podkarpackim, podlaskim, świętokrzyskim i warmińsko-mazurskim. Są to województwa, które stanowią wschodnią granicę UE, o podobnym stopniu i profilu

\footnotetext{
${ }^{15}$ Na przykład Biuro Regionalne Województwa Lubelskiego funkcjonuje w ramach Departamentu Promocji i Turystyki Urzędu Marszałkowskiego jako stanowisko ds. promocji województwa w UE. W urzędzie utworzono również lustrzane stanowisko ds. współpracy z biurem w Brukseli. Zob. http://www.um.bip.lublin.pl/index.php?id=26\&p0=szczegoly\&p1=107 (dostęp: 21.10.2012).. Podobnie Biuro Regionalne Województwa Podlaskiego w Brukseli funkcjonuje jako zamiejscowe stanowisko pracy w Departamencie Współpracy z Zagranicą i Promocji. W województwie podkarpackim biuro znajduje się w strukturach gabinetu marszałka, a zastępca dyrektora gabinetu pełni jednocześnie funkcję dyrektora przedstawicielstwa województwa w Brukseli. Zob. Zarządzenie Nr 21/2011 Marszałka Województwa Podkarpackiego z dnia 31 marca $2011 \mathrm{r}$. w sprawie określenia organizacji wewnętrznej oraz szczególowego zakresu działania Gabinetu Marszalka http://www.wrota.podkarpackie.pl/res/bip/um/org/2011/org_wew/2011_21.pdf. (dostęp: 21.10.2012). W województwie mazowieckim biuro przedstawicielskie działa w ramach kancelarii marszałka i jest merytorycznie nadzorowane przez jej dyrektora. Zob. Regulamin organizacyjny Urzędu Marszałkowskiego Województwa Mazowieckiego w Warszawie, Załącznik do Uchwały nr 2522/214/12 Zarządu Województwa Mazowieckiego z dnia 4 grudnia 2012, http://www.bip.mazovia.pl/urzad/regulamin-organizacyjny-umwm/ (dostęp: 21.10.2012).
} 
rozwoju społeczno-ekonomicznego. Dom Polski Wschodniej powstał w celu koordynacji i wzmocnienia działań pięciu przedstawicielstw regionalnych w Brukseli. U podstaw jego stworzenia legło przekonanie władz regionalnych, że wspólne przedstawicielstwo Dom Polski Wschodniej umożliwi pełniejsze wykorzystanie atutów oraz głównych szans rozwojowych, w tym wspólnego potencjału inwestycyjnego województw Polski Wschodniej, a także pozwoli skuteczniej zabiegać o wspólne interesy regionów w ramach Unii Europejskiej oraz przeciwdziałać wspólnym zagrożeniom. Nie bez znaczenia był również argument dotyczący zmniejszenia kosztów administracyjnych utrzymywania biur w Brukseli. W pierwszym roku działalności Domu każde z województw poniosło koszty w wysokości ok. 300 tys. złotych ${ }^{16}$. W kolejnych latach koszty te zwiększyły się do ok. 500 tys. złotych ${ }^{17}$.

Połączone siły pięciu regionów mają służyć realizacji wielu wspólnych inicjatyw, nie oznacza to jednak braku samodzielności i autonomii poszczególnych reprezentacji regionalnych $w$ realizacji zadań powierzonych im przez ich samorządy. Organizację i zapewnienie technicznych warunków funkcjonowania Domu - w tym wynajęcie wspólnej siedziby, zorganizowanie wspólnego sekretariatu i prowadzenie bieżącej obsługi finansowo-księgowej - powierzono województwu warmińsko-mazurskiemu. Natomiast koszty funkcjonowania ponoszone są przez wszystkie województwa. Koordynatorami aktywności Domu w zakresie wspólnych działań i reprezentacji na forum wszelkich instytucji Unii Europejskiej są kolejno marszałkowie poszczególnych województw. Elementem łączącym wszystkich reprezentantów jest sekretariat odpowiedzialny za obsługę wspólnych inicjatyw, a także wspomagający pracę koordynatora ${ }^{18}$. Tworzeniu „ambasady Polski Wschodniej”, jak czasami szumnie określano Dom Polski Wschodniej, towarzyszyły ogromne oczekiwania i nadzieje na lepszą promocję makroregionu i skuteczniejsze wykorzystanie wspólnego potencjału inwestycyjnego województw Polski Wschodniej, które należą do najbiedniejszych regionów UE. Pojawiały się również głosy sceptyczne co do możliwości pogodzenia, często konkurencyjnych, interesów poszczególnych województw.

Regionalne Biuro Województwa Łódzkiego w Brukseli powstało w 2004 r. Na mocy porozumienia o współpracy pomiędzy władzami województwa łódzkiego i miasta Łodzi określono formułę współpracy pomiędzy obiema instytucjami w zakresie działalności placówki, powołując działającą w ramach Biura sekcję miasto Łódź, kierowaną przez oddelegowanego przez prezydenta przedstawiciela miasta. Funkcjonowanie biura jest finansowane według proporcji:

\footnotetext{
${ }^{16} \mathrm{http}: / /$ rzeszow.gazeta.pl/rzeszow/1,34975,7132375,Wojewodztwa_Polski_Wschodniej_raze m_w_Brukseli.html (dostęp: 23.10.2012)..

${ }^{17} \mathrm{http} / / /$ www.tvp.pl/bialystok/aktualnosci/spoleczne/dom-kosztow/8887366 (dostęp: 23.10.2012)..

18 Porozumienie zawarte $w$ dniu 2 grudnia 2009 r. w Brukseli pomiędzy: Województwem Lubelskim, Województwem Podkarpackim, Województwem Podlaskim, Województwem Świętokrzyskim $i$ Województwem Warmińsko-Mazurskim, Dz.Urz. Województwa Świętokrzyskiego 2010 nr 190, poz. 1778; Regulamin działania Domu Polski Wschodniej w Brukseli.
} 
55\% Urząd Marszałkowski i 45\% Urząd Miasta Łodzi ${ }^{19}$. Łódź jest jedynym polskim miastem posiadającym swoją reprezentację w Brukseli ${ }^{20}$.

Dwa województwa wybrały formułę uruchomienia biur regionalnych w Brukseli poprzez stowarzyszenia. Regionalne Biuro Województwa Dolnośląskiego działa od 2001 r. - początkowo jako Stowarzyszenie Dolny Śląsk w Unii Europejskiej, a od 2004 r. jako jednostka budżetowa w całości finansowana przez Urząd Marszałkowski Województwa Dolnośląskiego ${ }^{21}$. Podobną formułę wybrało województwo pomorskie. Biuro Regionalne Województwa Pomorskiego w Brukseli zostało założone w 2004 r. przez Stowarzyszenie „Pomorskie w Unii Europejskiej", które jest formą partnerstwa regionalnego samorządów województwa pomorskiego (22 miasta, gminy i powiaty), uczelni oraz innych instytucji ${ }^{22}$.

Większość polskich województw przy organizacji i funkcjonowaniu biur regionalnych, zwłaszcza w początkowym okresie, skorzystała $\mathrm{z}$ doświadczeń i pomocy regionów partnerskich z Europy Zachodniej. Pomoc ta była realizowana $\mathrm{w}$ różnej formule: od stażu oddelegowanych pracowników administracji samorządowej $\mathrm{w}$ biurach regionalnych regionów partnerskich, przez pomoc w wynajmowaniu lokali dla przedstawicielstw, po konkretną współpracę i wsparcie finansowe. Województwo dolnośląskie ulokowało swoje przedstawicielstwo (2003) w brukselskiej siedzibie partnerskiego regionu West Midlands, województwo opolskie (2001) przy przedstawicielstwie Nadrenii-Palatynatu, świętokrzyskie (2003) w budynku przedstawicielstwa hrabstwa Aarthus, a warmińsko-mazurskie (2003) przy Europejskim Biurze Południowej Szwecji, gdzie mają swoje siedziby liczne biura regionów nadbałtyckich tworzące tzw. Grupę Palmerston. Następnie samodzielna już siedziba biura znajdowała się w tym samym budynku zwanym „Domem Bałtyckim”23. Biuro Regionalne Województwa KujawskoPomorskiego w latach 2004-2005 zlokalizowane było przy brukselskim biurze francuskiego regionu Midi-Pyrenees, które finansowało koszty biura przez pierwszy rok jego funkcjonowania ${ }^{24}$. Ostatnie polskie województwo - lubuskie (2005) - otworzyło swoje biuro w Brukseli we współpracy z prowincją duńską Ribe-Amt ${ }^{25}$

Jeszcze inną drogę utworzenia biura regionalnego w Brukseli wybrało województwo podlaskie. W 2003 r. podpisało porozumienie o współpracy z Wło-

\footnotetext{
${ }^{19} \mathrm{http}: / /$ www.bruksela.lodzkie.pl/pl/informacje/ (dostęp:30.09.2012)..

${ }^{20} \mathrm{~W}$ latach 2004-2007 funkcjonowało również przedstawicielstwo miasta Krakowa w Brukseli. http://www.bip.krakow.pl/?sub dok id=17445 (dostęp:30.09.2012).

${ }^{21} \mathrm{http}: / /$ www.umwd.dolnyslask.pl/index.php?id=3338 (dostęp: 30.09 .2012$)$..

22 http://www.pomorskie-eu.pl/pl/o-stowarzyszeniu.html. Zob. także Rola Biura Regionalnego Województwa Pomorskiego w Brukseli, http://www.pomorskie.eu/res/z_regionu/wspolpraca/rola_biura.pdf (dostęp: 28.10.2012)..

$23 \mathrm{http} / / /$ wrota.warmia.mazury.pl/Biuro-w-Brukseli/O-nas/Informacje-ogolne.html (dostęp: 28.10.2012).

${ }^{24} \mathrm{http}$ ://mojregion.eu/biuro-w-brukseli/informacje-ogolne.html (dostęp: 25.10.2012).

${ }^{25} \mathrm{http}: / /$ www.bruksela.lubuskie.pl/strona,29,Nasze Biuro (dostęp: 25.10.2012).
} 
sko-Polską Izbą Gospodarczą, która reprezentuje region Lombardii w kontaktach międzyregionalnych. Realizując zapisy porozumienia samorząd województwa, po przeprowadzonej analizie, przyjął propozycję Włochów w sprawie otwarcia siedziby Biura Regionalnego Województwa Podlaskiego w Brukseli (2004). Pomieszczenie wynajmowane było w jednym budynku z Włosko-Polską Izbą Gospodarczą, włoską firmą doradczą Sineura oraz reprezentantem rządu włoskiego w Brukseli ${ }^{26}$.

\section{PODSTAWY PRAWNE DZIAŁANIA BIUR}

Zgodnie z art. 172 Konstytucji RP jednostka samorządu terytorialnego ma prawo przystępowania do międzynarodowych zrzeszeń społeczności lokalnych i regionalnych oraz współpracy ze społecznościami lokalnymi i regionalnymi innych państw. Jednocześnie zaznaczenia wymaga fakt, iż aktywność jednostek samorządu terytorialnego w tym zakresie powinna odbywać się w granicach zadań i kompetencji tych jednostek, zgodnie z polskim prawem wewnętrznym, polityką zagraniczną państwa i jego międzynarodowymi zobowiązaniami.

Ramy współpracy zagranicznej polskich województw określają następujące akty prawne: Ustawa o samorządzie województwa z $1998 \mathrm{r}^{27}$, Ustawa o zasadach przystępowania jednostek samorządu terytorialnego do międzynarodowych zrzeszeń społeczności lokalnych i regionalnych z $2000 \mathrm{r}^{28}{ }^{2}$, uchwały sejmików województwa, określające priorytety współpracy zagranicznej, podpisane przez Polskę traktaty i konwencje międzynarodowe, wewnętrzne prawodawstwo RP związane z polityką zagraniczną oraz strategię polityki zagranicznej RP.

Brak jest przepisów prawnych regulujących zakładanie i funkcjonowanie biur regionalnych w Brukseli. Regiony państw członkowskich, korzystając ze swobodnego przepływu usług i siły roboczej, otwierają swoje biura bez przeszkód. Biura przedstawicielskie regionów europejskich $\mathrm{w}$ Brukseli, w tym zwłaszcza biura reprezentujące stolice państw, są tworzone na podstawie różnych rozwiązań prawnych: niektóre organizowane są zgodnie $\mathrm{z}$ prawem publicznym, inne - zgodnie z prawem cywilnym. Często są silnie powiązane $\mathrm{z}$ administracją regionalną. Niektóre biura działają wyłącznie jako ,wysunięte ramię" organu regionalnego i wspierają gospodarkę danego regionu. Personel biur jest w większości przypadków wybierany i finansowany przez administra-

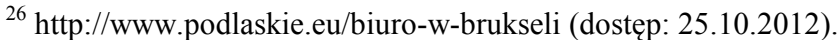

${ }^{27}$ Ustawa z dnia 5 czerwca 1998 r. o samorządzie województwa, Dz.U. z 2001 r., nr 142, poz. 1590 z późn. zm.

${ }^{28}$ Ustawa z dnia 15 września 2000 r. o zasadach przystepowania jednostek samorzadu terytorialnego do międzynarodowych zrzeszeń społeczności lokalnych i regionalnych, Dz.U. z 2000r., nr 91, poz. 1009.
} 
cję regionu, zatrudnieni pracownicy otrzymują instrukcje $\mathrm{z}$ regionu oraz zobowiązani są do składania regularnych raportów ze swej działalności ${ }^{29}$.

Biura regionalne nie posiadają statusu dyplomatycznego. Regiony nie są podmiotami prawa międzynarodowego, w związku z tym nie korzystają z prawa legacji. Nie są akredytowane ani przy władzach belgijskich, ani przy Unii Europejskiej. Nie korzystają z przywilejów i immunitetów dyplomatycznych.

Zgodnie z interpretacją MSZ utworzenie biura informacyjnego regionu polskiego w Brukseli należy traktować jako inicjatywę zagraniczną, a zatem władze regionalne muszą przedłożyć do MSZ stosowny wniosek i wszelkie wymagane dokumenty (uchwała sejmiku wojewódzkiego jako organu kompetentnego do podejmowania decyzji budżetowych) z prośbą o wydanie opinii w tej sprawie. Po uzyskaniu pozytywnej opinii MSZ biuro takie może formalnie rozpocząć swoją działalność, regulując jednocześnie wszelkie kwestie związane z jego rejestracją w Brukseli.

Założenie biura regionalnego w Brukseli wymaga spełnienia wymagań formalno-prawnych określonych prawem belgijskim. W celu ułatwienia zakładania regionalnych biur reprezentacyjnych radni Regionu Stołecznego Brukseli powołali Biuro ds. Kontaktów Brukseli z Europą: Bureau de Liaison BruxellesEurope. Nowo otwierane biuro musi złożyć w nim komplet dokumentów, na podstawie których Minister Stosunków Zewnętrznych Rządu Regionu Stołecznego Brukseli podejmuje decyzję o przyznaniu biuru akredytacji. Akredytacja potwierdza wypełnienie przez biuro wszystkich wymogów formalno-prawnych określonych prawem belgijskim oraz uznaje biuro, w świetle prawa belgijskiego, za jednostkę reprezentującą dany region ${ }^{30}$. Certyfikat ten nie ma żadnych implikacji prawnych. Ułatwia jedynie kontakty administracyjne ${ }^{31}$. Legalizacja biura w Brukseli nadaje mu status, dzięki któremu pracownicy biura są zapraszani na spotkania, konferencje, seminaria i inne wydarzenia dotyczące spraw unijnych. Co więcej, dzięki spełnieniu wszystkich wymogów biuro zyskuje legitymizację wśród instytucji unijnych oraz innych biur regionalnych. Tak więc zdobycie akredytacji otwiera drzwi do wielu źródeł informacji, do których nie ma dostępu biuro komercyjne czy podmiot niezatwierdzony oficjalnie przez władze Regionu Stołecznego Brukseli ${ }^{32}$.

\footnotetext{
${ }^{29}$ www.pomorskie.eu/res/wizytowka/wspolpraca/biura_regionalne (dostęp: 25.10.2012).

${ }^{30} \mathrm{http}: / /$ blbe.be/en/regional-certificate (dostęp: 15.10.2012).

31 B. De Schutter, The legal personality of regional representation offices, $\mathrm{http} / / / \mathrm{blbe} . \mathrm{be} / \mathrm{sites} / \mathrm{default} / \mathrm{files} / \mathrm{blbe} / \mathrm{files} /$ Representations_regionales/The_legal_personality_of_re gional_representation_offices.pdf (dostęp: 02.09.2012).

${ }^{32}$ Rola Biura Regionalnego Województwa Pomorskiego w Brukseli. Zob. także http://www.blbe.be/en/how-open-regional-office-brussels (dostęp: 26.10.2012).
} 
Polskie biura regionalne wynajmują pomieszczenia na swoje siedziby, starając się o ich dobrą lokalizację. Jedynie województwo mazowieckie zakupiło w 2008 r. w Brukseli budynek na własność ${ }^{33}$.

Biura działają na podstawie statutów i regulaminów organizacyjnych, które określają zadania i cele biur oraz ich tryb funkcjonowania. Zwierzchnikiem dyrektora biura jest marszałek województwa, natomiast sprawy proceduralne i organizacyjne są koordynowane przez odpowiedni wydział w urzędzie marszałkowskim $^{34}$ (czasami określany jako biuro lustrzane). W przedstawicielstwach polskich zatrudnia się na ogół od 1 do 5 osób. Dysponują budżetem w granicach 100-150 tys. euro. Środki te są przeznaczane na wynajem pomieszczeń, płace pracowników i cele reprezentacyjne.

\section{FUNKCJE I ZADANIA BIUR REGIONALNYCH}

W literaturze najczęściej wymienia się pięć rodzajów funkcji biur regionalnych ${ }^{35}$. Pierwszą z nich jest funkcja informacyjna. Składają się na nią z jednej strony pozyskiwanie i przekazywanie do regionu informacji na temat programów i nowych inicjatyw UE dostępnych dla danego regionu, informacji o procedurach i decyzjach ustawodawczych, a z drugiej, dostarczanie instytucjom UE oraz innym partnerom (np. przedstawicielom innych biur regionalnych) szczegółowych informacji na temat regionu. Ważnym instrumentem polityki informacyjnej jest strona internetowa biura. Znajdują się na niej wiadomości o wydarzeniach w Brukseli, najważniejszych decyzjach zapadających w instytucjach Unii Europejskiej, informacje o konkursach i grantach, konferencjach, szkoleniach oraz ogłoszenia o poszukiwaniu partnerów do przedsięwzięć finansowanych z programów UE. Strona prezentuje także informacje o poszczególnych województwach. Strony internetowe polskich biur regionalnych są bardzo zróżnicowane pod względem jakościowym ${ }^{36}$. Inne narzędzia to mailing (przesyłanie informacji określonym osobom i instytucjom drogą elek-

33 http://www.mazovia.pl/aktualnosci/art,1309, nowa-siedziba-biura-przedstawicielskiego-wbrukseli.html (dostęp: 25.10.2012).

${ }^{34}$ M. Sapała, R. Banaś, Regionalne przedstawicielstwa w Brukseli-paradyplomatyczna ofensywa polskich województw, w: Regiony w procesie integracji europejskiej, pod red. E. Małuszyńskiej, Poznań-Leszno 2005, s. 172.

${ }^{35}$ A. Heichlinger, op. cit., s. 15-18.

${ }^{36}$ Zdecydowanie najlepsze strony internetowe mają biura województw śląskiego, wielkopolskiego i łódzkiego. Oprócz informacji standardowych zamieszczanych na stronach wszystkich biur, znajdują się tam również roczne sprawozdania z działalności tych placówek, które dają przejrzysty obraz ich aktywności. Osobną kwestią są strony internetowe biur w języku angielskim, które prezentują się dosyć skromnie. Należałoby oczekiwać znacznie więcej informacji o regionach, pracy biur, wydarzeniach przez nie organizowanych, a nie informacji kopiowanych z oficjalnych stron instytucji UE. Na przykład strona anglojęzyczna Domu Polski Wschodniej zawiera tylko 2 informacje z 2012 roku o pracy Domu i wydarzeniach przez niego organizowanych! 
troniczną), czy monitorowanie prac komisji parlamentarnych. Jak twierdzi eurodeputowany Jan Olbrycht, ,nie można ulegać stereotypowi, że celem biura jest załatwianie pieniędzy z funduszy strukturalnych. Promowanie regionu to obecnie również zadanie wtórne. Podstawowym jego celem jest pozyskiwanie i dystrybuowanie informacji. Z tym, że priorytetem powinno być przekazywanie informacji o inicjatywach wspólnotowych do Polski"37. Szczególnie istotne znaczenie ma tzw. informacja szara, to znaczy niepubliczna, ale dostępna, nienaruszająca klauzuli tajności, często zdobywana poprzez kontakty towarzyskie $^{38}$. Jej pozyskanie i przekazanie przed oficjalnym ogłoszeniem umożliwia wczesną reakcję władz samorządowych czy innych zainteresowanych podmiotów w regionie i daje czas na właściwe przygotowanie się ${ }^{39}$. Analizując aktywność polskich biur regionalnych w Brukseli można stwierdzić, że pozyskiwanie, gromadzenie i przekazywanie informacji należy do najważniejszych funkcji i zajmuje najwięcej miejsca w ich pracy.

Druga istotną funkcją jest funkcja lobbingowa (na rzecz przyjmowania jak najkorzystniejszych z punktu widzenia regionu rozwiązań i decyzji). Adresatami lobbingu przedstawicielstw regionalnych są instytucje UE: Komisja Europejska, Parlament Europejski, Rada UE (najlepiej przez Stałe Przedstawicielstwo przy UE, bo Rada reprezentuje interesy narodowe), Komitet Regionów (małe zainteresowanie przedstawicieli regionów) ${ }^{40}$. Podstawowe instrumenty lobbingu to: utrzymywanie formalnych i nieformalnych kontaktów z politykami, urzędnikami, posłami; uczestnictwo w grupach roboczych Komisji, uczestnictwo w konferencjach, seminariach; prezentowanie priorytetów, problemów oraz planów rozwojowych regionu $\mathrm{w}$ trakcie różnego rodzaju spotkań z przedstawicielami KE, Komitetu Regionów oraz instytucji europejskich i przedstawicieli innych regionów. Polskie biura regionalne, mimo że w oficjalnych sprawozdaniach oraz na stronach internetowych wykazują dużą aktywność konferencyjną i seminaryjną $^{41}$, nie są zbyt skuteczne w prowadzeniu lobbingu. W związku z tym coraz częściej współpracują w ramach szerszych grup lobbingowych i sieci tematycznych, bądź monitorują działania takich grup ${ }^{42}$.

\footnotetext{
${ }^{37} \mathrm{http}: / /$ edgp.gazetaprawna.pl/index.php?act=mprasa\&sub=article\&id=124416 (dostęp: 03.09.2012)

${ }^{38}$ F. Skawiński, Reprezentacja interesów regionów w Unii Europejskiej, Warszawa 2008, s. 197

${ }^{39}$ D. Berlińska, L. Nijakowski, Lobbing na rzecz polskich regionów w Brukseli-przygotowanie do aktywnego czlonkostwa w Unii Europejskiej, Opole 2001, s. 146.

${ }^{40}$ F. Skawiński, op. cit., s. 203-210.

${ }^{41}$ Na przykład Biuro Regionalne Województwa Śląskiego w sprawozdaniu z działalności w roku 2011 wykazało aktywny udział w prawie 30 konferencjach i seminariach. Zob. http://brws.silesia-region.pl/zalaczniki/2012/10/11/1349951830/1349951909.pdf. (dostęp: 05.11.2012) W okresie polskiej prezydencji w Radzie UE wyraźnie wzrosła aktywność polskich biur w organizacji konferencji i spotkań.

${ }^{42} \mathrm{Na}$ przykład Biuro Regionalne Województwa Śląskiego monitoruje działalność Automotive Intergroup, Intergrupy ds. przyszłości przemysłu motoryzacyjnego na naszych terenach czy Grupy lobbingowej ds. korytarza Bałtyk-Adriatyk. Biuro Regionalne Województwa Wielkopolskiego
} 
Trzecią funkcję można określić jako networking, a więc budowanie sieci powiązań: służenie jako punkt kontaktowy dla przedstawicieli innych regionów zainteresowanych nawiązaniem kontaktu $\mathrm{z}$ danym regionem i aktywne poszukiwanie tego rodzaju kontaktów dla swojego regionu; wyszukiwanie partnerów do współpracy i realizacji projektów. W tym zakresie rola biur regionalnych sprowadza się głównie do przesyłania do regionu informacji dotyczących partnerów do realizacji projektów, na przykład Biuro Województwa Śląskiego w 2011 roku przygotowało i przesłało 174 takie informacje ${ }^{43}$, Biuro Województwa Wielkopolskiego umieściło na stronie internetowej ok. 40 informacji ${ }^{44}$.

Czwarta funkcja to funkcja promocyjna: promowanie potencjału gospodarczego i walorów turystycznych danego regionu; organizowanie imprez mających na celu prezentowanie i promowanie dorobku kulturalnego danego regionu współpraca $\mathrm{z}$ innymi instytucjami polskimi działającymi w Brukseli, praca z mediami. Biura są kulturalnymi ambasadami regionów w Brukseli. Prezentują walory swoich regionów podczas tradycyjnych imprez organizowanych dla i przez regiony reprezentowane w Brukseli, takich jak Open Doors Day ${ }^{45}$ czy Święto Alei Tervuren ${ }^{46}$. Przygotowują stoiska z materiałami promocyjnymi i produktami regionalnymi, ale również organizują wystawy, koncerty, przyjęcia ${ }^{47}$, patronują szkoleniom czy konferencjom. Jakość tej promocji w dużej mierze zależy od środków finansowych, jakie na ten cel wyasygnują poszczególne województwa, ale również duże znaczenie ma kreatywność, zdolności organizacyjne odpowiedzialnych za promocję przedstawicieli $\mathrm{z}$ regionów i pracowników biur regionalnych. Jak

z kolei uczestniczy w Sieci Monitorowania Strategii „Europa 2020” oraz Sieci Monitorowania Subsydiarności (w ramach sieci Komitetu Regionów). Włączyło się również w prace Sieci Regionów Podmiejskich - PURPLE, której głównym celem jest szersze uwzględnienie problematyki regionów obejmujących metropolie oraz rozległe tereny podmiejskie $w$ politykach unijnych oraz sieci regionów CORAL - wspólnoty regionów na rzecz życia wspieranego przez otoczenie, której działalność skupia się na wsparciu seniorów w społeczeństwie informacyjnym. Biuro Informacyjne Województwa Pomorskiego uczestniczy w sieci ERRIN (European Regions Research and Innovation Network), która jest siecią partnerów europejskich stworzoną w celu pomagania i wspierania regionów w pełnym i efektywnym uczestniczeniu w Europejskim Obszarze Badawczym.

43167 ofert przesłanych do regionu oraz 7 przesłanych z regionu do BRWS i rozesłanych do europejskich biur regionalnych z prośbą o przekazanie wiadomości potencjalnie zainteresowanym podmiotom w ich regionach.

$44 \mathrm{http}: / /$ www.wielkopolska.eu/images/sprawozdania/sprawozdanie_roczne_biww_2011.pdf. (dostęp: 03.09.2012). Ponadto informacje o poszukiwaniu partnerów do projektów są bezpośrednio przesyłane do jednostek administracji samorządowej, środowisk nauki, kultury i biznesu, członków polskiej delegacji do Komitetu Regionów, organizacji pozarządowych oraz polskich i zagranicznych regionów za pomocą elektronicznego biuletynu BIWW.

${ }_{45}$ Co roku, w rocznicę podpisania deklaracji Schumana, instytucje unijne otwierają swoje drzwi dla obywateli, chcąc w ten sposób przybliżyć im swoją działalność. Komitet Regionów udostępnia przestrzeń dla regionów, które mogą w ten sposób zaprezentować swoje walory.

${ }^{46}$ Aleja Tervuren to jedna $z$ najpiękniejszych, najstarszych i najdłuższych ulic Brukseli. Co roku 1 czerwca, z okazji urodzin Alei, odbywa się festyn będący jedną z najpopularniejszych imprez ulicznych wśród mieszkańców Brukseli.

${ }^{47}$ Chociażby tradycyjne polskie wigilie organizowane corocznie przez polskie regiony. 
wynika ze sprawozdań polskich biur regionalnych, działania w zakresie promocji regionów były wyjątkowo intensywne w okresie polskiej prezydencji w Radzie $\mathrm{UE}^{48}$.

W ramach funkcji wspierającej biura regionalne mają za zadanie pomoc przedstawicielom regionu w Komitecie Regionów, Komitecie Społeczno-Ekonomicznym, Parlamencie Europejskim, przygotowywanie wizyt polityków oraz ekspertów, organizację stażu dla pracowników administracji publicznej regionu czy organizację spotkań z przedstawicielami instytucji europejskich. Funkcja ta jest dosyć intensywnie realizowana przez wszystkie polskie biura regionalne. Często krytycy celowości utrzymywania biur w Brukseli i efektywności ich pracy określają je jako „biura podróży” dla urzędników administracji samorządowej. Należy jednak zauważyć również pozytywną rolę biur w tym zakresie. Staż, czy nawet krótkie wizyty studyjne, dobrze zorganizowane i wykorzystane, są ważnym źródłem wiedzy o funkcjonowaniu instytucji UE i możliwością zdobycia doświadczenia.

$\mathrm{Z}$ analizy statutów, regulaminów organizacyjnych i stron internetowych polskich biur regionalnych wynika, iż wszystkie realizują podobne funkcje. Różnie jedynie rozłożone są priorytety w ich realizacji. Do zadań stawianych przed biurami regionalnymi należą przede wszystkim: reprezentowanie interesów regionu wobec instytucji UE oraz innych regionów, budowanie relacji z regionami europejskimi, monitorowanie działań instytucji europejskich, gromadzenie i przekazywanie informacji ważnych z punktu widzenia interesów województwa, ułatwianie dostępu do środków unijnych, promocja i tworzenie dobrego wizerunku regionu, wyszukiwanie i pośrednictwo w zdobywaniu partnerów, doradztwo dla przedsiębiorców, lobbing na rzecz składanych do Komisji Europejskiej projektów.

\section{OCENA FUNKCJONOWANIA}

Biura regionalne są swoistymi ,ambasadami” regionów w Brukseli. W swoich zadaniach i funkcjonowaniu są paradyplomatycznym odpowiednikiem przedstawicielstw państw przy organizacjach międzynarodowych. Stanowią środek do zapewnienia wielu celów za pomocą jednego narzędzia - kontakty zarówno w ramach UE, jak i bezpośrednie kontakty z przedstawicielami innych regionów. Lokalizacja biura w Brukseli daje regionom możliwość wykorzystania

\footnotetext{
${ }^{48} \mathrm{~W}$ wyniku ścisłej współpracy szesnastu przedstawicielstw polskich regionów, w ramach polskiej Prezydencji w Radzie Unii Europejskiej odbył się w Brukseli cykl czterech konferencji na wysokim szczeblu: „Miejski wymiar Polityki Spójności”, „TEN-T na rzecz inteligentnego oraz zrównoważonego rozwoju regionów”, „Lokalny i regionalny wymiar Partnerstwa Wschodniego” oraz „Przyszłość Strategii UE dla regionu Morza Bałtyckiego - innowacje i transfer wiedzy”. Zwieńczeniem przedsięwzięcia było tradycyjne przyjęcie wigilijne - wydarzenie o charakterze promocyjno-kulturalnym zorganizowane przez polskie biura regionalne.
} 
efektu synergii, wynikającego ze zlokalizowania wielu przedstawicielstw regionalnych w jednym miejscu ${ }^{49}$.

Funkcjonowanie polskich biur regionalnych jest oceniane bardzo różnie. Często pojawiają się pytania o celowość otwierania biur oraz wątpliwości dotyczące współmierności kosztów funkcjonowania i efektów ich pracy ${ }^{50}$. Jednak wszystkie samorządy wojewódzkie, dostrzegając przydatność reprezentacji w Brukseli, zdecydowały o utworzeniu swoich biur.

Powszechnie najlepiej oceniana jest aktywność przedstawicielstw województw: śląskiego, pomorskiego, dolnośląskiego, mazowieckiego i łódzkiego. Można określić kilka czynników, które mają bezpośredni lub pośredni wpływ na jakość funkcjonowania polskich biur regionalnych:

- Środki finansowe - wynajęcie i utrzymanie biura, pensje personelu i cele reprezentacyjne. $\mathrm{W}$ przypadku polskich przedstawicielstw regionalnych są to kwoty rzędu 80-150 tys. euro ${ }^{51}$. Na tle dużych regionów z państw zachodnioeuropejskich nie są to kwoty duże ${ }^{52}$, niemniej skłaniają do dyskusji na poziomie województw na temat opłacalności utrzymywania biur w Brukseli.

- Czynnik ludzki - powszechnie uważa się, że sprawnie funkcjonujące biuro powinno zatrudniać minimum 6 osób. Duża część polskich biur są to przedstawicielstwa jednoosobowe, więc chociażby z tego powodu ich aktywność jest bardzo ograniczona. Małe biura realizują wybrane zadania w ograniczonym zakresie, zajmując się np. tylko jednym obszarem tematycznym i programami z nim związanymi. Ich aktywność nie może być jednak ograniczona do roli „biura podróży" dla regionalnych i lokalnych samorządowców, powielania informacji dostępnych w Internecie, czy czasami siermiężnej promocji regionu. Coraz więcej biur zatrudnia obecnie po kilka osób: śląskie, łódzkie i wielkopolskie po 4 osoby, pomorskie i zachodniopomorskie po 3 pracowników. Niewątpliwie znajduje to odzwierciedlenie w większej efektywności i skuteczności pracy biura.

${ }^{49}$ K. Szmigiel, Regionalne, po co i z kim? Relacje międzynarodowe polskich województw, Warszawa 2009, s. 103-104.

${ }^{50}$ Na przykład dosyć krytyczne oceny efektów działania Domu Polski Wschodniej formułowali radni Sejmiku Województwa Podlaskiego. Podkreślali, że najbardziej widocznym efektem pracy Domu jest strona internetowa, a „organizowanie wystaw czy rezerwacja hoteli dla samorządowców przyjeżdżających do Brukseli nie może stanowić alibi dla istnienia tego Domu". Członek zarządu województwa podlaskiego podał dwa przykłady dotychczasowych osiągnięć Domu Polski Wschodniej - wystawę zdjęć promującą region oraz wydanie podręcznika do nauki tolerancji. W ciągu ponad dwóch lat Urząd Marszałkowski na utrzymanie biura w Brukseli przeznaczył ponad milion złotych. Zob. http://www.tvp.pl/bialystok/aktualnosci/spoleczne/dom-kosztow/8887366 (dostęp: 15.10.2012).

${ }^{51} \mathrm{Na}$ przykład koszt wynajęcia i utrzymania biura województwa lubelskiego wynosi 300 tys. zł, do tego należy dodać wynagrodzenie dla przedstawiciel; , koszt utrzymania biura województwa łódzkiego w 2009 r. wyniósł 603 tys. zł, a w 2010 r. 520 tys. zł (300 tys. przeznaczył Urząd Marszałkowski, a 222 tys. Urząd Miasta). Zob. http://www.bruksela.lodzkie.pl/export/sites/bruksela/pl/download/Sprawozdanie_2010.pdf (dostęp: 02.09.2012).

${ }^{52}$ Duże regiony zachodnioeuropejskie wydają na funkcjonowanie swoich biur w Brukseli nawet 1,5 mln euro rocznie. Zob. F. Skawiński, op. cit., s. 216. 
Przeważnie są to ludzie młodzi, dobrze wykształceni, znający języki obce, ale często dopiero uczący się poruszania w świecie instytucji unijnych (są to na ogół urzędnicy urzędów marszałkowskich oddelegowani do pracy w Brukseli). Ich pozycja w hierarchii urzędniczej jest dosyć słaba. Często zdarza się, że po krótkim czasie i tzw. „przetarciu się” się w Brukseli znajdują pracę lepiej płatną w instytucjach unijnych. Dla biura oznacza to brak ciągłości funkcjonowania i konieczność zatrudniania nowej osoby ${ }^{53}$. Najbardziej optymalnym rozwiązaniem byłoby powierzanie kierowania przedstawicielstwami regionalnymi osobom, które mają już wiedzę i doświadczenie pracy w instytucjach UE, ale także znajomość polskiej administracji i procedur administracyjnych.

- Dobrze sformułowana strategia funkcjonowania biura - w zdecydowanej większości władze województwa nie mają pomysłów na właściwe i optymalne wykorzystanie swoich biur regionalnych w Brukseli. Często więc przedstawiciele regionalni nie mają jasno sprecyzowanych oczekiwań co do ich aktywności i celu działania.

- Dobra współpraca zarówno na szczeblu europejskim, jak i regionalnym znacznie lepszą skuteczność w działaniu mają biura regionalne województw, które dobrze współdziałają z regionalnymi europarlamentarzystami (najczęściej jest tak w przypadku zgodności opcji politycznych). Równie istotna jest dobra współpraca z podmiotami regionalnymi - potencjalnymi beneficjentami pracy biur. Rezultaty pracy biur często trafiają $\mathrm{w}$ próżnię. Wynika to $\mathrm{z}$ braku ich promocji $\mathrm{w}$ regionie. $\mathrm{W}$ tym kontekście istotne jest, aby $\mathrm{w}$ administracji samorządowej zatrudnieni byli pracownicy (lub pracownik) odpowiedzialni za kontakty z biurem w Brukseli ${ }^{54}$. Większość polskich województw bądź posiada tzw. biura lustrzane, bądź zatrudnia pracownika, którego głównym zadaniem jest współpraca $\mathrm{z}$ biurem ${ }^{55}$.

Polskie biura regionalne można uznać za szkołę samorządności na płaszczyźnie międzynarodowej. Oficjalnie mówi się, że są narzędziem promocji na zewnątrz, że potrafią lepiej od przedstawicielstw centralnych, takich jak ambasady, konsulaty, przedstawicielstwa handlowe, dopasować działania do atutów

\footnotetext{
${ }^{53}$ F. Skawiński, op. cit., s. 211.

${ }^{54}$ Jak pisze M. Sapała, nie może to być dodatkowe, drugorzędne zadanie dla jakiegoś pracownika w regionie, gdyż niezwykle istotne jest szybkie i właściwe wykorzystanie informacji. Zob. M. Sapała, Rola władz terytorialnych w Unii Europejskiej. Formy reprezentacji interesów na forum europejskim, Poznań 2005, s. 66.

${ }^{55} \mathrm{Na}$ przykład w Urzędzie Marszałkowskim województwa lubuskiego funkcjonuje biuro lustrzane Brukseli, działające w ramach Wydziału Współpracy Zagranicznej w Departamencie Rozwoju Regionalnego i Współpracy Zagranicznej. Zob. http://www.bruksela.lubuskie.pl/strona,29,Nasze_Biuro (dostęp: 21.10.2012). Natomiast w Urzędzie Marszałkowskim województwa lubelskiego w ramach Departamentu Promocji i Turystyki funkcjonuje stanowisko ds. współpracy z biurem w Brukseli. Do obowiązków zatrudnionego na tym stanowisku pracownika należy przede wszystkim merytoryczne wsparcie biura w Brukseli oraz prowadzenie spraw organizacyjnych wynikających $\mathrm{z}$ utrzymywania przedstawicielstwa województwa lubelskiego w Brukseli. Zob. http://www.um.bip.lublin.pl/index.php?id=26\&p0=szczegoly\&p1=108 (dostęp: 21.10.2012).
} 
i słabości danego województwa. W praktyce jednak różnie z tym bywa. Niewątpliwie stanowią ważny punkt kontaktowy pomiędzy instytucjami unijnymi a regionami, usprawniają komunikację, przyczyniają się do wczesnej identyfikacji zarówno zagrożeń i obszarów problemowych, jak i szans rozwojowych dla regionów. Analizując ich funkcjonowanie, należy zauważyć wzrastający poziom profesjonalizacji ich działania. Ocena efektywności ich funkcjonowania jest jednak dosyć trudna. Słusznie zauważa Magdalena Sapała, że przy takiej ocenie zawsze trzeba mieć na uwadze kontekst szerszej europejskiej strategii władz regionu. Jeżeli biuro regionalne jest elementem dobrze skonstruowanej strategii, ma jasno sprecyzowane zadania, może być skutecznym narzędziem realizacji celów samorządu wojewódzkiego.

\section{„EMBASSIES” FOR REGIONS: REPRESENTATION OF POLISH VOIVODSHIPS IN BRUSSELS}

Summary. The main purpose of the article is the analysis of the organizational forms, functions and activity of the Brussels offices of Polish regions as well as an attempt to evaluate their effectiveness. The presence of sub-national authorities representations dates from the mid-1980s. At the moment over 300 regional offices are present in Brussels. They represent all the Polish regions. Polish regional offices are public initiatives, mainly being part of regional governments. They do not enjoy diplomatic status, but they are a kind of paradiplomatic ,embassies” of their regions. The main functions of the offices can be summarized in five areas of activity: information management, networking, providing liaison between regional authorities and the EU, influencing of the EU policy, and the promotion of Polish regions. The activity of Polish regional offices is evaluated ambivalently. The most frequent questions concern the usefulness of their establishing and the commensurability of their maintenance costs with the results of their work.

Key words: regions, regional offices, paradiplomacy, European Union 